A N N A L E S

UNIVERSITATIS MARIAE CURIE-SKŁODOWSKA

LUBLIN - POLONIA

VOL. LXIX, z. 1-2

SECTIO F

Uniwersytet Marii Curie-Skłodowskiej w Lublinie

Wydział Humanistyczny

MATEUSZ PAZGAN

\title{
Zagadnienia aprowizacji ludności województwa wrocławskiego z perspektywy starostwa kamiennogórskiego w latach 1945-1947
}

Problems Victualing Wrocław Region's Population from the Perspective of the County in the Years 1945-1947

\section{STRESZCZENIE}

Wśród wielu problemów mających miejsce po II wojnie światowej ważne były sprawy zaopatrzenia, którymi zajmowali się przedstawiciele polskiej administracji ogólnej, a szczególnie referat aprowizacji. Brak żywności powodowało wiele czynników, m.in. słabe uprawy rolne. Aby zapewnić aprowizację mieszkańcom, wprowadzono kartki żywnościowe, które zostały podzielone na kategorie, do których przypisano odpowiednie grupy społeczne i odpowiednią ilość żywności. Podział na kategorie dotyczył głównie mieszkańców miast. Mieszkańcy wsi, którzy posiadali gospodarstwa, byli zobowiązani do dostarczania tzw. świadczeń rzeczowych, nazywanych w czasie wojny kontyngentami. Wymiana żywności odbywała się w czasie publicznych spędów bydła. Korzystano również z formy zewnętrznej, tzw. paczek UNRRA, które stawały się substytutami zamiennymi kartek żywnościowych. Na przełomie 1946 i 1947 r. na ziemiach zachodnich odbyło się też jednorazowe świadczenie, tzw. danina narodowa. Pomoc wewnętrzna i zewnętrzna w aprowizacji mieszkańców zaowocowała niewielką poprawą jakości życia. Należało jednak opracować kolejne plany poprawy zaopatrzenia w żywność, pierwszym z nich był plan 3-letni.

Słowa kluczowe: aprowizacja; karty żywnościowe; paczki UNRRA; świadczenia rzeczowe (kontyngenty); danina narodowa; starostwo

\section{WPROWADZENIE}

II wojna światowa spowodowała przesunięcie polskich granic o $200 \mathrm{~km}$ na zachód, po rzeki Odrę i Nysę Łużycką. Wymusiło to przesiedlenie wielu milionów Polaków ze wschodu na zachód. Wojna spowodowała również braki w za- 
opatrzeniu w podstawowe artykuły spożywcze i codziennego użytku. Już w okresie okupacji, zarówno w Generalnym Gubernatorstwie, jak i na terenach wchłoniętych do III Rzeszy, obowiązywały kartki żywnościowe, reglamentacja żywności i kontyngenty.

Sytuacja nie poprawiła się wraz z ustaniem działań wojennych, a w niektórych obszarach wręcz się pogorszyła. Widoczne jest to głównie na terenach ziem zachodnich i północnych Polski, gdzie Niemcy kradli jedzenie od Polaków, a sami Polacy wobec siebie nie byli wyrozumiali. Niezbędne minimum spożycia dla dorosłego człowieka wynosiło wówczas ok. 1350 kalorii. W rzeczywistości wielu ludzi spożywało codziennie tylko do 700 kalorii. Wówczas podnoszono ilość kalorii przez picie alkoholu pochodzącego najczęściej z przydomowej produkcji. Z czasem racje żywności się zwiększały i osiągnęły standardową normę dzienną wynoszącą ok. 2200 kalorii $^{1}$.

\section{REFERAT APROWIZACJI W STAROSTWIE POWIATOWYM}

Sprawami zaopatrzenia w pierwszych latach po zakończeniu II wojny światowej zajmował się referat aprowizacji. Do jego zadań należało: zaopatrywanie mieszkańców we wszelkie artykuły reglamentowane, głównie żywność, m.in. ziemiopłody (zboża), produkty pochodzenia zwierzęcego, takie jak mięso (drób, wołowina, wieprzowina), tłuszcze, jaja, mleko, oraz artykuły spożywcze pochodzenia roślinnego; nadzorowanie sklepów i miejsc rozdzielczych na terenie powiatu, głównie Powszechnej Spółdzielni Spożywców „Społem” i Grupy Spółdzielczej „Samopomoc Chłopska”; kontrola powiatowych i miejskich mleczarni, piekarni, masarni, zakładów gastronomicznych, restauracji, paszteciarni, piwiarni, jadłodajni, herbaciarni oraz sklepów spożywczych, galanteryjnych i tekstylnych.

Obowiązkiem wicestarosty było zwoływanie Komisji Kontrolno-Kwalifikacyjnej w przypadkach zepsucia żywności. Towarami reglamentowanymi były w większości także artykuły przemysłowe, wszelkie wyroby tekstylne, obuwie, opał i materiały pędne, które były rozdzielane według wytycznych z urzędu wojewódzkiego ${ }^{2}$.

Wraz z kierownikiem referatu w komórce tej pracowali podreferenci w roli kontrolerów. Działali oni na zlecenie starosty lub kierownika referatu. Było ich siedmiu: podreferent ogólny, planowania, ziemiopłodów, handlu, obrotu zwierzęcego, przemysłu spożywczego i artykułów przemysłowych ${ }^{3}$. Do ich zadań nale-

${ }^{1}$ Wywiad Marcina Mellera z Marcinem Zaremba, Czas strachu, „Newsweek. Historia” 2012, nr 4, s. 43; A. Jezierski, B. Petz, Historia gospodarcza Polski Ludowej 1944-1985, Warszawa 1988, s. 75.

${ }^{2}$ Archiwum Państwowe we Wrocławiu, Oddział w Jeleniej Górze (dalej: APJG), Starostwo Powiatowe w Kamiennej Górze (dalej: SPKG), sygn. 181, k. 17-18; APJG, SPKG, sygn. 109, s. 14-16.

${ }^{3}$ APJG, SPKG, sygn. 173, s. 25. 
żało: sprawdzanie przestrzegania tzw. dni bezmięsnych ${ }^{4}$ i bezciastkowych ${ }^{5}$ (dni, w których była zakazana sprzedaż tego typu towarów), prawidłowego rozdzielania kart żywnościowych dla odpowiednich grup; terminowe rozliczanie gmin ze zwrotu tych kart; sprawdzanie przepisów dotyczących uboju zwierząt; kontrola młynów, sprawy przemiału zboża, świadczeń rzeczowych, paczek UNRRA ${ }^{6}$; wszelkie inne przepisy wchodzące w zakres działania referatu aprowizacji ${ }^{7}$.

\section{ZAOPATRYWANIE LUDNOŚCI NIEROLNICZEJ POWIATU KAMIENNOGÓRSKIEGO W ŻYWNOŚĆ I ARTYKUŁY CODZIENNEGO UŻYTKU}

Jedną z głównych bolączek społeczeństwa, wraz z napływem ludności na ziemie zachodnie, były problemy z aprowizacją. Mieszkańcy powiatu nieposiadający własnych gospodarstw rolnych, przede wszystkim ludność miejska, dostawali ze swoich urzędów miejskich kartki na żywność, które pochodziły ze świadczeń rzeczowych i darów UNRRA ${ }^{8}$. Referenci aprowizacji ze starostwa wydawali miesięczne karty żywnościowe - podzielone na kategorie I, II, III, IR i IIR, do tego dochodziły dodatki S (dla mieszkańców Warszawy), D1, D2, D3 (dla dzieci do lat odpowiednio 3, 7 i 12), M (mieszkaniowy), C (dla ciężko pracujących) i Rol. (rolniczy) - urzędnikom gminnym, a ci przekazywali je bezpośrednio mieszkańcom. Przydział kartkowy do odpowiednich kategorii (i względnie dodatek) zależał od zajęcia, którym trudniła się ludność nierolnicza.

Kategorię I otrzymywali: pracownicy zakładów, instytucji i fabryk państwowych oraz samorządowych; pracownicy zakładów, instytucji, fabryk i organizacji prywatnych o stawkach płacy odpowiadających cenom artykułów reglamentowanych, a więc zbliżonym do płac pracowników i instytucji państwowych; osoby wykonujące pracę nieposiadającą stałego charakteru, a uznaną za ważną ze społecznego punktu widzenia, np. artyści, literaci, dziennikarze czy duchowieństwo; pracownicy organizacji społecznych (np. Caritas); studenci wyższych uczelni, o ile rodzice nie posiadali więcej niż 2 ha ziemi; pacjenci szpitali; członkowie rodzin osób powołanych do Wojska Polskiego?.

${ }^{4}$ Ibidem, sygn. 190, s. 2. Dni bezmięsne to dni bez możliwości zakupu w sklepie bądź restauracji produktów pochodzenia mięsnego, w województwie wrocławskim obowiązywały w latach 1945-1948 w środy, czwartki i piątki, od 1 grudnia 1948 r. był to wtorek, środa i czwartek.

${ }^{5}$ Ibidem. Dni bezciastkowe to dni bez możliwości zakupu w sklepie bądź restauracji wyrobów z cukru, w województwie wrocławskim obowiązywały w latach 1945-1950 we wtorki, w środy, czwartki i piątki.

${ }^{6}$ UNRRA (United Nations Relief and Rehabilition Administration) - Administracja Narodów Zjednoczonych do Spraw Pomocy i Odbudowy.

${ }^{7}$ APJG, SPKG, sygn. 173, s. 8.

${ }^{8}$ R. Bertisch, Materiaty do dziejów organizacji osadnictwa wiejskiego na Dolnym Śląsku w latach 1945-1946, „Śląski Kwartalnik Historyczny Sobótka” 1956, nr 3, s. 420.

${ }^{9}$ APJG, SPKG, sygn. 188, s. 1-2. 
Kategorię II przyznawano: pracownikom spółdzielni i firm prywatnych wchodzących w skład skupu lub rozdziału, niekorzystającym z kart kategorii I; osobom niezdolnym do pracy, inwalidom wojennym i wojskowym; dozorcom domowym; emerytom, o ile nie posiadali gospodarstwa większego niż 2 ha; rzemieślnikom zrzeszonym w cechach, którzy zawarli umowy na dostawy po ustalonych cenach; prawnikom należącym do rad prawniczych; farmaceutom, w tym pracownikom aptek ${ }^{10}$.

Kategorię III otrzymywali: pracownicy zakładów przemysłowych i budowlanych, z wyłączeniem właścicieli tych zakładów; osoby uznane przez lekarzy, względnie powiatowe ośrodki zdrowia, za niezdolne do pracy i niebędące na utrzymaniu pracowników; kobiety samotnie wychowujące nieletnie dzieci na podstawie zaświadczeń miejskich, względnie powiatowych ośrodków zdrowia, repatrianci, przesiedleńcy i uchodźcy na jeden miesiąc po osiedleniu się w nowym miejscu zamieszkania; osoby w wieku 60 lat i więcej; osoby zamieszkujące domy starców; osoby pozbawione prawomocnym wyrokiem sądu powszechnych praw wyborczych bądź ubezwłasnowolnione ${ }^{11}$.

Kategorie IR przyznawano: wszystkim członkom rodzin pracowników otrzymujących kartki żywnościowe z kategorii I i II; chorym dzieciom przebywającym w szpitalach (plus podwójna dawka mleka i cukru); młodzieży szkolnej przebywającej w bursach, kwaterach lub internatach (plus normy stołówki szkolnej); żonom i ich nieletnim dzieciom, o ile nie mają innego żywiciela na podstawie zaświadczenia miejscowego referatu opieki społecznej; żonom, których mężowie milicjanci zostali zabici na posterunkach lub w czasie akcji; osobom zamordowanym przez Niemców, o ile żony nie posiadały gospodarstwa rolnego ponad 2 ha; drugim i kolejnym członkom rodzin zmobilizowanych do Wojska Polskiego mężczyzn, o ile nie posiadali pola rolnego o powierzchni przekraczającej 2 ha $^{12}$.

Ostatnią kategorię IIR otrzymywali członkowie rodzin kobiet samotnie wychowujących niepełnoletnie dzieci, otrzymujących karty żywnościowe III kategorii ${ }^{13}$.

Na każdą z wymienionych powyżej kategorii i dodatków składała się odpowiednia ilość przydziału miesięcznego żywności. Osoby pobierające kartki żywnościowe kategorii I dostawały miesięczne: $8,5 \mathrm{~kg}$ chleba, $2 \mathrm{~kg}$ mąki pszennej, $1 \mathrm{~kg}$ kaszy, 0,5 kg cukru, 0,4 kg soli, 1 kg tłuszczu, 1 puszkę konserwy 964-gramowej, $0,5 \mathrm{~kg}$ marmolady oraz 20 dag herbaty. Osoby otrzymujące przydział z kategorii II dostawali: 6,5 kg chleba, 1,5 kg mąki pszennej, 0,4 kg cukru, 0,4 kg soli, 0,75 kg thuszczu, 0,5 kg kaszy, 1 puszkę konserwy 794-gramowej i 15 dag herbaty. Racje żywnościowe w kategorii III były następujące: 5 kg chle-

\footnotetext{
${ }^{10}$ Ibidem, s. 2.

${ }^{11}$ Ibidem.

${ }^{12}$ Ibidem.

${ }^{13}$ Ibidem.
} 
ba, $1 \mathrm{~kg}$ mąki pszennej, $0,2 \mathrm{~kg}$ soli i $0,75 \mathrm{~kg}$ śledzi. Osoby z kategorii IR dostawały kartki żywnościowe na: $6 \mathrm{~kg}$ chleba, $1 \mathrm{~kg}$ mąki pszennej, 0,25 kg cukru, 0,3 kg soli, $0,5 \mathrm{~kg}$ thuszczu, $1 \mathrm{~kg}$ śledzi, 10 dag herbaty. Osoby, którym przyznano kategorię IIR dostawały takie same karty żywnościowe, co osoby przypisane do kategorii III. Na dodatek „D” (dziecięcy) składała się 1 tabliczka czekolady o wadze $113 \mathrm{~g}, 0,65 \mathrm{~kg}$ mleka w proszku, 0,5 $\mathrm{kg}$ sera $\mathrm{z}$ darów UNRRA, 0,25 $\mathrm{kg}$ cukru, 2 kg mąki pszennej z darów UNRRA. Dodatek „M” (mieszkaniowy) zawierał 250 dag sera tłustego i 250 dag cukru. Dodatek "C" (dla ciężko pracujących) zawierał $4 \mathrm{~kg}$ chleba, 0,5 kg śledzi i 250 dag sera półtłustego. Dodatek „S” (stolica) był przyznawany tylko osobom posiadającym w Warszawie kategorię I i był równoważny z dodatkiem „C" ${ }^{\prime 14}$.

Żywność była wydawana w urzędach gmin w referatach biurach aprowizacji. Niewykorzystane przez mieszkańców karty żywnościowe nie przechodziły na kolejny miesiąc. Musiały być zwrócone do gminy właściwej dla miejsca zamieszkania lub zameldowania. W gminie odbywało się komisyjne niszczenie kart żywnościowych.

\section{POMOC UNRRA I ZWIĄZKU RADZIECKIEGO}

Po II wojnie światowej początkowo władze komunistyczne nie zrezygnowały z pomocy zewnętrznej, pochodzącej z Ameryki Północnej. Do czasu odrzucenia przez rząd Polski tzw. planu Marshalla w lipcu 1947 r., do kraju spływały tzw. paczki UNRRA. Była to międzynarodowa organizacja humanitarna powstała w 1943 r. w celu łagodzenia skutków działań wojennych i niesienia pomocy, szczególnie dzieciom, których rodzice zginęli na frontach i w obozach pracy w trakcie II wojny światowej. Na kanwie tej organizacji powołano w 1947 r. UNICEF przy Organizacji Narodów Zjednoczonych, zajmujący się niesieniem pomocy dzieciom w biednych krajach świata.

W Polsce UNRRA zyskała pieszczotliwy przydomek „ciocia UNRRA”. Było to w pełni uzasadnione. Paczki stanowiły swego rodzaju substytut zastępczy jedzenia, mięso zastępowały ryby, bo - jak to argumentowano - „ilość kalorii jest podobna, białko to samo, a rybie mięso to jak by nie patrzeć też mięso"15. W gazetach zamieszczano również krótkie fraszki i rymowanki, jak np. taki limeryk z wrocławskiego „Słowa Polskiego”:

Piotruś w biedzie,

Na wieś jedzie,

Oczywiście zbiera liście

${ }^{14}$ Ibidem, s. 2-3; APJG, SPKG, sygn. 180, s. 4-5.

${ }^{15}$ Pod znakiem dorsza i łososia. Wcale nie dziwne historie z paczkami cioci UNRRA, „Naprzód Dolnośląski”, 28 maja 1946, nr 89, s. 3. 
Trzeba forsy?

Papierosy

I na mieście

UNRRA - wrzeszczy! ${ }^{16}$

Zasady pomocy UNRRA były proste i przejrzyste. Kraje niezniszczone w rezultacie działań wojen z lat 1939-1945, m.in. Kanada czy Stany Zjednoczone, zobowiązały się wpłacać na rzecz organizacji pieniądze, za które UNRRA kupowała żywność, lekarstwa i inne towary, m.in. samochody, ciągniki czy nawet zwierzęta, jak np. konie, co później stało się epizodem w kultowej polskiej komedii Sami swoi w reż. Sylwestra Chęcińskiego z 1967 r. Następnie towary na wielkich statkach były przewożone z Ameryki Północnej na Stary Kontynent, a tu je odpowiednio rozdysponowywano na poszczególne obszary Europy. UNRRA w każdym kraju, któremu udzielała pomocy, posiadała swego przedstawiciela w postaci szefa misji. W Polsce był nim D. Sabin ${ }^{17}$.

Sytuacja w Polsce na wiosnę 1946 r. była wręcz dramatyczna, w związku z czym postanowiono w przypadku reglamentowanej żywności i kartek zaopatrzeniowych zastąpić kategorię I i II paczkami UNRRA, które stały się substytutem zastępczym podziału na kategorie zaopatrzeniowe. Rozdawanie darów UNRRA jako towaru zastępczego było przydzielane tym samym sposobem, co kartki na żywność I i II kategorii. W skład zamiennika wchodziło $2 \mathrm{~kg}$ mięsa, $1 \mathrm{~kg}$ tłuszczu i 0,5 kg cukru ${ }^{18}$. Mieszkańcom Dolnego Śląska na 95 wagonach towarowych przywieziono 677870 kg żywności, które rozdysponowano na poszczególne powiaty ${ }^{19}$.

Jednakże nie wszystkie osoby przydzielone do I kategorii dostały odpowiednie substytuty zastępcze, często zdarzało się, że podarunki UNRRA były zapowiedziane przez miejscowe władze do odbioru, ale na wyznaczony czas nie docierały do odbiorców, gdyż były szabrowane przez milicjantów, którzy byli „ubogimi krewnymi” funkcjonariuszy Urzędu Bezpieczeństwa, lub inne zorganizowane grupy. Paczki UNRRA w zastępstwie dostali: pracownicy urzędów rządowych ogólnych, wojewódzkich i powiatowych; pracownicy urzędów samorządu terytorialnego i gospodarczego; pracownicy pocztowi; nauczyciele; pracownicy Zakładu Ubezpieczeń Społecznych; pracownicy przemysłów metalowych, chemicznych, paliwowych, zbrojeniowych, obuwniczych, energetycznych, papierniczych, budowlanych, włókienniczych, drzewnych, elektrotechnicznych oraz mo-

${ }^{16}$ Ostatnia strona, „Słowo Polskie”, 13 listopada 1946, nr 13, s. 8.

${ }^{17}$ APJG, Powiatowa Rada Narodowa w Kamiennej Górze (dalej: PRNKG), sygn. 99, s. 1; Z pobytu gen. Dyrektora UNRRA w Warszawie, ,Trybuna Dolnośląska”, 26 kwietnia 1947, nr 96, s. 2.

${ }^{18}$ Kto otrzyma paczki żywnościowe UNRRA, „Pionier”, 17 kwietnia 1946, nr 91, s. 4.

${ }^{19}$ E. Paliński, Organizacja i formy działania opieki społecznej na Dolnym Śląku w latach 1945-1946, „Śląski Kwartalnik Historyczny Sobótka” 1967, nr 1-2, s. 542. 
nopolu solnego; pracownicy portów i żeglugi śródlądowej oraz instytucji społecznych; osoby prowadzące ciągniki rolnicze; personel szpitalny ${ }^{20}$.

Zazwyczaj paczki UNRRA były darem dla biednych mieszkańców wsi i miast od władz misji. Lekarstwa UNRRA dostawali lekarze, którzy rozdysponowywali je swoim pacjentom. O rzeczy materialne, potrzebne w codziennej pracy, np. samochody czy zwierzęta, zazwyczaj toczyły się publiczne loterie z udziałem miejscowych władz administracyjnych. Niektóre zwierzęta w czasie loterii należało oswoić, gdyż były dzikie. Właśnie tę scenę przedstawiono w filmie Sami swoi, gdzie Witia oswaja ogiera, którego potem przyprowadza do domu Pawlaków. Były również w paczkach UNRRA takie towary, które nie pasowały ani na loterię, ani do darów. Były to przede wszystkim takie używki, jak papierosy i alkohol. Takie towary przekazywano do Gminnych Spółdzielni „Samopomoc Chłopska” lub do Powszechnej Spółdzielni Spożywców „Społem”21. Towary w postaci ubrań, bielizny i butów były przekazywane do Wojewódzkich Kuratoriów Oświaty, a stąd do Powiatowych Inspektoratów Szkolnych, które dostarczały „dziatwie szkolnej amerykańskie ubrania”, szczególnie dzieciom rodziców zza Buga ${ }^{22}$.

Ówczesna prasa polska dosyć dokładanie śledziła losy paczek UNRRA. Udzielała wręcz wskazówek jak należy korzystać z amerykańskich soków:

1. Soki pomidorowe, a) Po otwarciu puszki - zawartość przelać natychmiast do czystego naczynia szklanego, b) Cała zawartość puszki winna być zużyta w ciągu 24 godzin, gdyż po tym czasie może podlegać szkodliwej fermentacji. 2. Soki owocowe, a) Zawartość puszki musi być natychmiast po otwarciu przelana do czystego naczynia szklanego i rozcieńczona taką samą ilością świeżej przegotowanej wody, b) Jedna osoba dziennie może wypić 1/4 do 1/2 litra soku owocowego rozcieńczonego, c) Rozcieńczonego płynu nie można przechowywać dłużej niż jeden dzień, gdyż może podlegać szkodliwej fermentacji. Soki owocowe z puszek wydętych (wybombowanych) nie mogą być spożywane ${ }^{23}$.

Działalność UNRRA miała się skończyć wraz z 1946 r., lecz została przedłużona o kolejny rok, mimo że w amerykańskich koncepcjach powstawał już tzw. plan Marshalla. Pomoc UNRRA okazała się doraźną i uratowała wielu ludzi przed zimnem, usprawniła zbiór zboża i ziemniaków czy po prostu uchroniła przed śmiercią głodową. Koordynatorem paczek UNRRA w powiatach były referaty aprowizacji, do których należało rozdawanie darów i gospodarowanie pustymi opakowaniami po paczkach UNRRA.

${ }^{20}$ Komunikat o przydziałach paczek UNRRA, „Naprzód Dolnośląski”, 3-4 maja 1946, nr 70, s. 6; Przydziaty paczek UNRRA, „Pionier”, 4 maja 1946, nr 104, s. 4.

${ }^{21}$ UNRRA dla najmłodszych, „Pionier”, 7 maja 1946, nr 106, s. 3.

${ }^{22}$ Ibidem.

${ }^{23}$ Jak używać soków UNRRA, „Naprzód Dolnośląski”, 14-15 lipca 1946, nr 127, s. 1; Soki UNRRA nadchodza „Pionier”, 23 maja 1946, nr 120, s. 5. 
Pomoc gospodarcza, jaką dostała Polska od ZSRR była niewspółmierna w porównaniu do pomocy amerykańskiej. Sowieci sami po II wojnie światowej mieli problemy agrarne, wiele hektarów ziem było zniszczonych i wypalonych, nie nadawały się do zasiewu. Trudno więc uznać tę pomoc za znaczącą. Propaganda wokół pomocy gospodarczej ze strony ZSRR dobitnie o tym świadczy, np. we wrześniu 1944 r. prawobrzeżna część Warszawy Praga dostała na rozkaz Józefa Stalina 10000 t mąki, gdzie w tym samym czasie jej lewobrzeżna część biła się z okupantem hitlerowskim o wolność i niepodległość ${ }^{24}$.

\section{ŚWIADCZENIA RZECZOWE}

Kolejną formą pomocy były świadczenia rzeczowe, czyli obowiązkowe dostawy produktów rolnych i hodowlanych, pobierane przez komisje świadczeń rzeczowych działające przy starostach i wojewodach przy udziale pracowników referatu aprowizacji. Świadczenia rzeczowe ludności zostały oparte na przedwojennej ustawie z 30 marca 1939 r. „O powszechnym obowiązku świadczeń rzeczowych". Ustawa całkowicie ustalała przygotowanie i przebieg świadczeń, które miały być przeprowadzone na wypadek wojny z Niemcami, co kilka miesięcy później stało się faktem ${ }^{25}$.

Mieszkańcy powołanego w październiku 1939 r. Generalnego Gubernatorstwa oraz terenów włączonych do III Rzeszy zostali zobowiązani również do obowiązkowych dostaw na rzecz okupanta. Świadczenia rzeczowe nazwano kontyngentami i później, po powołaniu w lipcu 1944 r. samozwańczego PKWN, używano tych nazw zamiennie. Nie zmienia to faktu, że kontyngenty były ściągane przez niemieckiego okupanta pod rygorem pójścia do obozu koncentracyjnego, a nawet pod groźbą śmierci. Nie dziwi więc, że źle były widziane przez Polaków po zakończeniu II wojny światowej ${ }^{26}$.

Niestety, pomoc zewnętrzna w postaci darów UNRRA tylko częściowo mogła zaspokoić oczekiwania mieszkańców wsi i miast. Było dużo czynników, z powodu których tzw. rząd lubelski powrócił do obowiązkowych świadczeń rzeczowych, m.in. wiele polskich miast było zburzonych, gospodarka polska poniosła znaczące straty zarówno w przemyśle ciężkim, jak i lekkim, na wsi panowało przeludnienie agrarne, istniały duże kontrasty społeczne - od bogatego chłopstwa zwanego kułakami do włościaństwa bezrolnego. Wprowadzona dekretem PKWN dnia 6 września 1944 r. tzw. reforma rolna rzeczywiście rozparcelowała ogromne posiadłości ziemskie i przekazała je chłopstwu małorolnemu lub bezrolnemu, szczególnie na ziemiach tzw. Polski centralnej. Jednakże w dalszym

\footnotetext{
${ }^{24}$ APJG, PRNKG, sygn. 99, s. 2.

${ }^{25}$ Dziennik Urzędowy Rzeczypospolitej Polskiej (dalej: Dz.Urz. RP) 1939, nr 30, poz. 200, art. $1-2$.

${ }^{26}$ R. Kaczmarek, Historia Polski 1914-1989, Warszawa 2010, s. 413, 415-416.
} 
etapie reformy okazało się to niewystarczające, gospodarstwa rolne nie stały się samowystarczalne. Dodatkowo poniemieckie grunty rolne przeszły na rzecz Skarbu Państwa, z których w późniejszym czasie powstawały Państwowe Gospodarstwa Rolne (PGR). Dekret z 1944 r. o reformie rolnej nie rozwiązał kwestii ziem tzw. martwej ręki (ziemia kościelna), które zajmowały znaczne obszary powojennej Polski. Dopiero po ustabilizowaniu się komunistycznej władzy PZPR wziął się za grabież majątku kościelnego ${ }^{27}$.

Wszystkie te czynniki powodowały, że niemożliwa była pełna aprowizacja mieszkańców wsi i miast. Ci ostatni, pracujący głównie w przemyśle i administracji, dostawali przydziały na kartki żywnościowe, co omówiłem wcześniej.

Kontyngenty były przez władzę ludową pomyślane w następujący sposób: oddajemy część zbiorów gospodarstwa rolnego na rzecz mieszkańców miast pracujących w przemyśle czy w administracji, a część zostaje właścicielowi pola, który z pozostawionych zbiorów musi wyżywić całą rodzinę. Świadczenia rzeczowe stawały się wewnętrzną sprawą województwa, gdyż nie było możliwości ich wywozu (szczególnie zboża poza teren województwa, czasami nawet powiatu), ponieważ kontyngenty traktowano jako mienie ruchome. Wszystko to tworzyło klimat kontyngentu jako zła koniecznego, oddawanego na rzecz państwa pod przymusem, pod rygorem kar grzywny, więzienia czy konfiskaty posiadanego pola ${ }^{28}$.

Propagandowa Polska Partia Robotnicza była przeciwnikiem świadczeń rzeczowych.

Jeszcze w zimie na pierwszym Krajowym Zjeździe PPR [grudzień 1945 r. - przyp. M. P.], partia nasza stwierdziła jasno i niedwuznacznie, że uważamy system kontyngentu za konieczny, ale konieczność przejściową, konieczność podyktowaną warunkami okresu wojennego i bezpośrednich następstw gospodarczych po wojnie. Jeszcze wtedy stwierdziliśmy, że będziemy dążyli do zniesienia tego systemu skoro tylko pozwolą na to warunki ${ }^{29}$.

W 1945 r. Pełnomocnik Rządu na Okręg Administracyjny Dolnego Śląska, Stanisław Piaskowski, wydał dla obwodów powiatowych i ich starostw „Instrukcję w sprawie wzmożenia realizacji świadczeń rzeczowych"30. Czytamy w niej:

Postawić sprawę realizacji świadczeń rzeczowych jako centralne zagadnienia gospodarstw w chwili obecnej i wciągnąć pracowników innych referatów starostwa do konkretnej pomocy aparatowi realizującemu świadczenia rzeczowe w ściąganiu kontyngentów. Należy opracować plan ich terenowego działania. Sprawozdania z działalności jak i postery realizowania świadczeń rzeczowych składać w Wojewódzkim Oddziale Świadczeń Rzeczowych. Dopilnować systematyczne-

${ }^{27}$ Ibidem, s. 562; A. Jezierski, B. Petz, op. cit., s. 100-101.

${ }^{28}$ Dz.Urz. RP 1939, nr 30, poz. 200, art. 3.

${ }^{29}$ PPR żąda zniesienia świadczeń rzeczowych, „Trybuna Dolnośląska”, 6 czerwca 1946, nr 94, s. 1.

${ }^{30}$ APJG, SPKG, sygn. 185, s. 207. 
go poruszania świadczeń rzeczowych przez prasę lokalną, zasilając ją odpowiednimi informacjami. W kampanii prasowej jak również radiowej należy podnosić nie tylko tak, jak dotychczas osiągnięcia, lecz również braki i najpilniejsze potrzeby. Urządzić ponownie zebrania masowe we wszystkich gminach, poświęcone popularyzowaniu świadczeń, wciągając do wystąpienia na tych zebraniach nie tylko członków partii, lecz również czynnika społecznego [tj. związek samorządowy i społeczność lokalną - M. P.], związki zawodowe, nauczycielstwo, duchowieństwo itp. ${ }^{31}$

W taki sposób miało miejsce wstępne rozpoznanie i przygotowanie mieszkańców powiatu do wymiany świadczeń rzeczowych, co leżało w gestii referentów aprowizacji. Kolejnym etapem była deklaracja, co dany gospodarz rolny przeznaczy na kontyngent, a następnie dzień świadczeń rzeczowych, które odbywały się trzy razy do roku: późną wiosną (koniec maja, początek czerwca), w okresie żniw i przed świętami Bożego Narodzenia ${ }^{32}$.

Wśród wartościowych produktów przeznaczanych stale na kontyngenty były ziemiopłody, a wśród nich zboże (głównie pszenica i żyto) i bydło, dalej wołowina i wieprzowina oraz mleko krowie bądź kozie. W czasie świadczeń rzeczowych bydła odbywały się spędy, czyli publiczne uboje. Czasami zdarzało się, że na świadczenia rzeczowe wystawione przez właściciela szło inne bydło niż zadeklarowane bądź, co gorsza, zarażone. Gospodarze najczęściej oszukiwali, podstawiając zamiast kozy owcę. Argumentowano to chorobami zwierząt, zagubieniem zwierzyny czy jej śmiercią.

Świadczenia rzeczowe, mimo niechęci i oporu społeczeństwa wiejskiego, przyniosły w miarę czasu stopniową poprawę warunków życia. W czasie kampanii przedreferendalnej „3 razy TAK” 30 czerwca 1946 r. komunistyczne władze zniosły je, zastępując towarami wolnorynkowymi. Następnie w 1947 r. powrócono do systemu świadczeń, którego ostateczna likwidacja nastąpiła wraz z końcem planu 3-letniego, kiedy gospodarka Polski Ludowej wróciła do pewnej równowagi33.

\section{DANINA NARODOWA}

Danina narodowa na zagospodarowanie Ziem Odzyskanych, bo taka była pełna nazwa, to jednorazowe powszechne świadczenie majątkowe na ,przyspieszenie zagospodarowania Ziem Odzyskanych i ekonomicznego zjednoczenia z Macierzą". Od daniny były zwolnione osoby fizyczne, takie jak inwalidzi wojenni, emeryci czy renciści, ale też osoby prawne, jak związki samorządu terytorialnego oraz majątki należące do Skarbu Państwa. Sami podejmowali decyzję, czy chcą złożyć dobrowolną daninę na rzecz ziem zachodnich ${ }^{34}$.

\footnotetext{
${ }^{31}$ Ibidem.

${ }^{32}$ Dz.Urz. RP 1939, nr 30, poz. 200, art. 17, 19.

${ }^{33}$ R. Kaczmarek, op. cit., s. 567.

${ }^{34}$ Dz.Urz. 1946, nr 61, poz. 341, art. 3-5; Danina Narodowa na zagospodarowanie Ziem Odzyskanych, „Naprzód Dolnośląski”, 15 listopada 1946, nr 230, s. 1.
} 
W przeciwieństwie do kontyngentów świadczenie nie było realizowane w naturze, tylko w ekwiwalencie pieniężnym. Wysokość daniny była zależna od wielkości gospodarstwa rolnego oraz stopnia miesięcznego wynagrodzenia za pracę bez względu na to, czy było to na terenach tzw. Polski centralnej, czy na ziemiach zachodnich.

Tab. 1. Wysokość daniny

\begin{tabular}{|c|c|}
\hline Obszar gospodarstwa rolnego & Ekwiwalent pieniężny w złotówkach \\
\hline do 2 ha & $150 \mathrm{zł}$ \\
\hline od 2 do 5 ha & $200 \mathrm{zł}$ \\
\hline od 5 do 10 ha & $250 \mathrm{zl}$ \\
\hline od 10 do 20 ha & $300 \mathrm{zl}$ \\
\hline od 20 ha do 30 ha & $400 \mathrm{z}$ \\
\hline powyżej 30 ha & $500 \mathrm{zł}$ \\
\hline Wynagrodzenie miesięczne za pracę & Wysokość daniny w procentach (zlotówkach) \\
\hline do $3000 \mathrm{zł}$ & $0,5 \%(\max 15 \mathrm{zl})$ \\
\hline od 3000 do $6000 \mathrm{zl}$ & $1 \%(30-60 \mathrm{zl})$ \\
\hline od 6000 do $12000 \mathrm{zł}$ & $3 \%(180-360 \mathrm{z})$ \\
\hline od 12000 do $20000 \mathrm{zł}$ & $5 \%(600-1000 \mathrm{zl})$ \\
\hline od 20000 do $50000 \mathrm{zl}$ & $8 \%(1600-4000 \mathrm{zl})$ \\
\hline $50000 \mathrm{zł} \mathrm{i} \mathrm{więcej}$ & $15 \%$ (min. $7500 \mathrm{zl})$ \\
\hline
\end{tabular}

Źródło: opracowanie własne na podstawie: Dz.Urz. 1946, nr 61, poz. 341, art. 6 § 1, art. $10 \S 1$.

Do ściągania daniny narodowej zostały powołane przez Prezydia Powiatowych Rad Narodowych powiatowe komisje obywatelskie. W skład każdej komisji wchodzili reprezentanci terenowych grup społecznych: pracowników przemysłu, rolnictwa, kupiectwa, rzemiosła i wolnych zawodów, najlepiej z grona członków Rad Narodowych, w liczbie od 5 do 20 włącznie, z którego wybierano przewodniczącego komisji. Dodatkowo powiatowe komisje obywatelskie powoływały sekretarza i jego zastępcę z przedstawicieli powiatowych Urzędów Skarbowych $^{35}$. Do zakresu ich kompetencji należało ustalanie wysokości daniny dla każdego mieszkańca gminy, jeżeli podlegał takiemu zobowiązaniu, sprawowanie nadzoru nad uiszczeniem opłaty oraz pomoc i współdziałanie w trakcie poboru, ściągania daniny przez właściwe władze i rozpatrywanie próśb, odwołań mieszkańców o obniżenie, względnie zwiększenie daniny narodowej ${ }^{36}$.

${ }^{35}$ Dz.Urz. 1946, nr 61, poz. 341, art. 22.

${ }^{36}$ Ibidem, art. 24. 
Wpłaty na daninę narodową obywały się na terenie całej Polski od 15 grudnia 1946 r. do 15 stycznia 1947 r. Warto zwrócić uwagę, że w tym samym czasie trwała kampania wyborcza do Sejmu Ustawodawczego, co ułatwiało ściąganie tego świadczenia. Jednakże wielu mieszkańców miast i wsi opierało się zapłacie na „zagospodarowanie na Ziemie Odzyskane". W takiej sytuacji danina narodowa stawała się zaległością wobec państwa polskiego i była egzekwowana przy udziale władz administracyjnych, względnie komorniczych ${ }^{37}$. Inną formą kary za uchylanie się za niepłacenie tego świadczenia było np. cofnięcie przez władze skarbowe koncesji na prowadzenie działalności gospodarczej, handlowej lub przemysłowej, a nawet cofnięcie prawa wykonywania zawodu w danym przedsiębiorstwie ${ }^{38}$.

Ówczesna prasa polska przedstawiała, jak wielkim czynem dla ziem zachodnich i zbawieniem jest danina narodowa: „Uchwalona danina będzie wyrazem woli całego narodu, wszystkich jego warstw i grup, umożliwi poważne zwiększenie inwestycji na Ziemiach Odzyskanych i wzmocnienie naszej potęgi gospodarczej. Będzie to najlepsza i najbardziej godna narodu naszego odpowiedź na zakusy protektorów i obrońców Niemiec"39.

Na podstawie zachowanych źródeł archiwalnych trudno przedstawić, jakie były efekty daniny narodowej, na co rzeczywiście przekazano pieniądze wpłacone przez Polaków na to świadczenie. Danina narodowa stała się elementem politycznej rozgrywki, z której komunistyczne władze miały więcej szkody niż pożytku. Nie zmienia to faktu, że w 1948 r. we Wrocławiu zorganizowano wielką tzw. Wystawę Ziem Odzyskanych, która miała przyćmić wszystkie podjęte do tej pory działania władz państwowych oraz przede wszystkim pokazać, jak ziemie ,jeszcze nie tak dawno zgermanizowane”, zostały złączone na trwałe z nową Polską - Polską Ludową. Fundusze na tę wystawę miały pochodzić z daniny narodowej. Tak to przedstawiał wrocławski pionier w pierwszych latach po wojnie ${ }^{40}$.

\section{PODSUMOWANIE}

Aprowizacja i zaopatrzenie mieszkańców ziem zachodnich w podstawowe artykuły spożywcze i przemysłowe odbywała się na kilku płaszczyznach. Mieszkańcy wsi wspomagali mieszkańców miast pracujących w przemyśle w posta-

${ }^{37}$ APJG, SPKG, sygn. 71, s. 2.

${ }^{38}$ Dz.Urz. 1946, nr 61, poz. 341, art. 40.

${ }^{39}$ Danina Narodowa na zagospodarowanie..., s. 1.

${ }^{40}$ W. Kania, Z pionierskich lat 1945-8, ,Śląski Kwartalnik Historyczny Sobótka” 1952, nr 1-2, s. 245; „Trzy lata pracował na Ziemiach Odzyskanych robotnik, rolnik, rzemieślnik, mechanik, malarz, rzeźbiarz, architekt, technik, inżynier, urzędnik, doktór, profesor, a w dodatku składał ciężko zapracowany grosz na premiową pożyczkę odbudowy kraju, składał na Daninę Narodową. Otwarta w lipcu 1948 r. Wystawa Ziem Odzyskanych pokazem swych eksponatów i wykresów potwierdziła, że ta praca nie poszła na marne". 
ci świadczeń rzeczowych, a te były zamieniane na kartki żywnościowe wydawane przez referaty aprowizacji. Jeżeli nie można było wydać kart żywnościowych, zastępowały je substytuty żywnościowe w postaci paczek UNRRA. Oprócz tego była „pomoc" ze strony Związku Sowieckiego. W konsekwencji danina narodowa miała stanowić próbę wsparcia już w postaci pieniężnej dla tzw. Ziem Odzyskanych, ale jej efekty są trudne do ustalenia, poza propagandową wystawą z $1948 \mathrm{r}$. we Wrocławiu. W wyniku tej pomocy życie mieszkańców na ziemiach zachodnich i północnych uległo pewnej poprawie. Należało opracowywać kolejne plany aprowizacyjne w następnych latach, a pierwszym z nich był plan 3-letni.

\section{BIBLIOGRAFIA}

\section{Źródła}

Archiwum Państwowe we Wrocławiu, Oddział w Jeleniej Górze, Starostwo Powiatowe w Kamiennej Górze, sygn. 71, 109, 173, 180, 181, 185, 188, 189.

Archiwum Państwowe we Wrocławiu, Oddział w Jeleniej Górze, Powiatowa Rada Narodowa w Kamiennej Górze, sygn. 99.

Danina Narodowa na zagospodarowanie Ziem Odzyskanych, „Naprzód Dolnośląski”, 15 listopada 1946, nr 230.

Dziennik Urzędowy Rzeczypospolitej Polskiej 1939.

Jak używać soków UNRRA, „Naprzód Dolnośląski”, 14-15 lipca 1946, nr 127.

Komunikat o przydziałach paczek UNRRA, „Naprzód Dolnośląski”, 3-4 maja 1946, nr 70.

Kto otrzyma paczki żywnościowe UNRRA, „Pionier”, 17 kwietnia 1946, nr 91.

Ostatnia strona, „Słowo Polskie”, 13 listopada 1946, nr 13.

Pod znakiem dorsza i łososia. Wcale nie dziwne historie z paczkami cioci UNRRA, „Naprzód Dolnośląski”, 28 maja 1946, nr 89.

Powiatowa Rada Narodowa w Kamiennej Górze.

PPR żąda zniesienia świadczeń rzeczowych, „Trybuna Dolnośląska”, 6 czerwca 1946, nr 94.

Przydziały paczek UNRRA, „Pionier”, 4 maja 1946, nr 104.

Soki UNRRA nadchodza „Pionier”, 23 maja 1946, nr 120.

UNRRA dla najmłodszych, „Pionier”, 7 maja 1946, nr 106.

Wywiad Marcina Mellera z Marcinem Zaremba, Czas strachu, „Newsweek. Historia” 2012, nr 4.

Z pobytu gen. Dyrektora UNRRA w Warszawie, „Trybuna Dolnośląska”, 26 kwietnia 1947, nr 96.

\section{Opracowania}

Bertisch R., Materiały do dziejów organizacji osadnictwa wiejskiego na Dolnym Ślasku w latach 1945-1946, „Śląski Kwartalnik Historyczny Sobótka” 1956, nr 3.

Jezierski A., Petz B., Historia gospodarcza Polski Ludowej 1944-1985, Warszawa 1988.

Kaczmarek R., Historia Polski 1914-1989, Warszawa 2010.

Kania W., Z pionierskich lat 1945-8, „Śląski Kwartalnik Historyczny Sobótka” 1952, nr 1-2.

Paliński E., Organizacja i formy działania opieki społecznej na Dolnym Ślasku w latach 1945-1946, „Śląski Kwartalnik Historyczny Sobótka” 1967, nr 1-2. 


\section{SUMMARY}

The problem of people messing in fundamental groceries after World War II was one of the major concerns of Polish general administration. This was due to various factors, including lack of agricultural crops. To ensure the provision of food supplies office paper in district offices was separating food stamps to the urban population engaged in the administration or industry. Food stamps were divided into categories, to which is assigned the right amount of food. The rural population was supplied by means of the so-called benefits in kind, called a tariff war. The exchange of food held at slaughter public three times a year. The form of external assistance was called UNRRA packages that have become a substitute for replacement food stamps. Between 1946 and 1947 the Recovered Territories held a so-called one-time benefit national tribute to the equivalent in cash. Internal and external assistance resulted in improved quality of life, however, was to be developed further assistance plans, the first of which was a Three-Year Plan.

Keywords: victualing; ration card; UNRRA packages; benefits in kind (contingent); national tribute; the county 